\title{
INSIDE THE NEW MARKETS TAX CREDIT PROGRAM: WHO IS THE REAL WINNER?
}

ROSHAN RAJABI 


\section{INTRODUCTION}

Congress established the New Markets Tax Credit (NMTC) program on December 21, 2000, as part of the Community Renewal Tax Relief Act. The Community Renewal Tax Relief Act of 2000 "create[d], extend[ed], and expand[ed] three vehicles [in order] to attract business investment and create employment opportunities in specific, designated geographic areas" (Fiore, 2001, p. 78). Those "vehicles" were renewal communities, empowerment zones, and community development entities. Congress implemented the NMTC program under the third vehicle-community development entities. Prior to the Community Renewal Tax Relief Act of 2000, the Internal Revenue Code "offered few incentives to either invest in, or make loans to, small businesses located in low-income communities. The new law change[d] this by providing tax incentives to those willing to invest in economically disadvantaged communities" (Fiore,2001, p. 78).

The purpose of the NMTC program is to encourage investment in low-income communities by providing incentives, in the form of tax credits against federal income taxes, for community development lenders and capital markets that invest in impoverished communities with limited access to capital. The overarching goal of the NMTC program is to break through the barriers that impede "conventional access to credit and investment capital for developing small businesses, creating and retaining jobs, and revitalizing neighborhoods [which] is often limited in economically distressed communities or in communities with large low-income populations" (Hardin, 2011, p. 27). One must note that although Democratic President Bill Clinton signed the act into law, it had bipartisan support. In fact, Republican William Archer introduced the Community Renewal Tax Relief Act to the House of Representatives on December 14, 2000. Further, Republican Speaker of the House Dennis Hastert worked alongside President Clinton in order to develop the New Markets Tax Credit program. In the beginning, the program was intended to be in place for seven years; however, throughout its life, it has been reauthorized and expanded numerous times.

Since its inception, the NMTC program has received substantial praise from politicians all across the spectrum, as well as from participating investors and borrowers. Noteworthy articles in support of the NMTC program include: The New Markets Tax Credit Progress Report 2016 by the New Markets Tax Credit Coalition, and "Credits \& Incentives Talk with Deloitte" by Kevin Potter. Despite its overwhelming support, two reports released in August 2014 raised questions about the legitimacy of NMTCs: one published by the Government Accountability Office (GAO) and the other by Senator Tom Coburn (R-OK). Those reports are titled New Markets Tax Credit: Better Controls and Data are Needed to Ensure Effectiveness and "Banking on the Poor," respectively. I will use these resources, both those in favor and in opposition of the NMTC program, to develop and analyze positions for and against the program. The concept of New Markets Tax Credits is unfamiliar to many working in and studying finance. Even some in the commercial banking field, where NMTCs are executed, are not particularly knowledgeable in terms of the details of the program. The goal of this research paper is to first familiarize readers with what NMTCs are, and also with how they are used by both commercial bankers and the businesses obtaining funding. To do so, I will lay out the design of the NMTC program, the criteria to be met in order to participate, and the process by which the NMTC program is implemented. Further, as discussed above, I will analyze arguments both for and against the NMTC legislation. I will then provide an assessment of the arguments and offer additional research to determine if the program is functioning as intended, or if one party benefits more than the other. Lastly, I will offer recommendations for how to improve the legislation.

\section{LITERATURE REVIEW}

\section{Overview}

A substantial amount of available information exists regarding New Markets Tax Credits, specifically regarding what they are, the purpose behind the NMTC program, the process in which they are obtained and used, and how they, theoretically, are beneficial to both the creditor/investor and borrower. Significant evidence also supports the NMTC program, proving its effectiveness in the American economy. Recently, however, the Government Accountability Office and Senator Tom Coburn brought the fairness of the program into question with reports titled Better Controls and Data are Needed to Ensure Effectiveness, and "Banking on the Poor," respectively. Those publications were met with momentous backlash from those in favor of NMTCs. I will analyze evidence that supports both sides of the issue in this section.

\section{Background of the New Markets Tax Credit Program}

While Bill Clinton's presidency was controversial to many, the country clearly experienced tremendous economic growth during his presidency from 1993 to 2001. As Clinton entered the office in 1993, he and his vice president, $\mathrm{Al}$ Gore, launched their economic strategy of: 
(1) establishing fiscal discipline, eliminating the budget deficit, keeping interest rates low, and spurring private sector investment;

(2) investing in people through education, training, science, and research; and

(3) opening foreign markets so American workers can compete abroad. (Clinton-Gore, 2001)

Between the day President Clinton and Vice President Al Gore took office and the year 2000, economic growth averaged four percent per year, the economy created over 22.5 million jobs, and real median family income increased over $\$ 6,000$ on average. Further, overall unemployment dropped "from 6.9 percent in 1993 to just 4.0 percent in November 2000" while unemployment for African Americans fell "from 14.2 percent in 1992 to 7.3 percent in October 2000" and unemployment for Hispanics decreased "from 11.8 percent in October 1992 to 5.0 percent in October 2000." Additionally, inflation was at a historic low, averaging 2.5\%, and fiscal year 2000 ended with a $\$ 237$ billion surplus for the American government (Clinton-Gore, 2001).

With all of the previously discussed accomplishments, and an approval rating of a significant 66 percent in December 2000 (Gallup, 2013), the Clinton administration was coming to an end-and it felt it still had significant work to do. Not everyone shared in the benefits of the mid-1990's strong economic growth, specifically, according to the Clinton administration, those in "urban, older suburban, and rural areas of distress" (Clinton-Gore, 2001).

In an attempt to finish strong, a mere two weeks prior to his term end, President Bill Clinton signed the Community Renewal Tax Relief Act into law, from which the New Markets Tax Credit program stemmed. President Clinton called this legislation the "most significant effort ever" to help low-income communities through private investment (Pappas, 2001, p. 323). Clinton worked closely with Republican Speaker of the House, Dennis Hastert, to produce this "package of incentives aimed at boosting economic circumstances in communities left behind by the prosperity of the 1990s," by using the tax code as opposed to federal grants (Walker, 2010, p.1).

The NMTC program was formed on the basis that access to capital is key to a business'ssuccess. A report from the NMTC Coalition explains that "the idea behind the NMTC legislation was that there are good business opportunities in low-income communities, but the cost and scarcity of capital in these 'New Markets' is a substantial impediment to spurring economic growth" (Walker, 2010, p. 3). One does not have to be an expert in finance to conclude that large banks typically would not consider lending to struggling and distressed small businesses located in low-income communities. This is simply because such businesses are at high risk of defaulting on loans. On the other hand, those struggling and distressed businesses would not typically seek loans from large, established banks out of a (perhaps justified) fear of being denied. In a way, the NMTC program is serving as a bridge to connect big banks to the low-income community businesses who so desperately need funding.

Since the NMTC program was initiated, Congress has authorized \$61 billion in NMTC allocations (Anderson, 2016). It began with a $\$ 15$ billion budget for 2001-2007, until Congress authorized an additional $\$ 1$ billion under the Gulf Opportunity Zone Act of 2005, specifically for communities affected by Gulf Coast hurricanes. Another $\$ 3.5$ billion was added through the Tax Relief and Health Care Act of 2006, and the Emergency Economic Stabilization Act of 2008 authorized an additional \$3.5 billion. The growth continued with the American Recovery and Reinvestment Act of 2009, which increased annual credit authority for 2008 and 2009 to $\$ 5$ billion. Both the Tax Relief, Unemployment Insurance Reauthorization and Job Creation Act of 2011 and the American Taxpayer Relief Act of 2012 gave the NMTC program two-year extensions with annual credit authority of $\$ 3.5$ billion. Most recently, in 2014, the Tax Increase Prevention Act extended the NMTC another $\$ 3.5$ billion.

Currently, the NMTC legislation is set to expire on December 31, 2019; however, the Preventing a Tax Hike (PATH) Act of 2015 is pending in both chambers of Congress. The PATH Act would extend the NMTC for five years, authorizing a total of $\$ 17.5$ billion to be allocated at $\$ 3.5$ billion per year-the NMTC's "longest and largest extension" (Anderson, 2016, p. 6). According to the NMTC Coalition's 2016 Progress Report:

The PATH Act will ensure the delivery of more than $\$ 30$ billion in new investments to businesses and projects in distressed neighborhoods and towns[,] creating tens of thousands of jobs through nearly 2,000 projects, including: new hospitals in medically underserved, rural areas; rejuvenated blighted urban corridors, revived manufacturing activity in regions where the last plant closed decades ago; and tens of thousands of square feet of newly constructed or renovated space for non-profit service providers, schools, daycare centers, and other important community facilities.

The bipartisan support behind the NMTC program has allowed for its continuous growth since its beginning in 2000. To reiterate the Program's continued support from both ends of the political spectrum, Senators Roy Blunt 
(R-MO) and Chuck Shumer (D-NY) introduced the New Markets Tax Credit Extension Act of 2015 to the Senate. Further, Representatives Pat Tiberi (R-OH), Richard Neal (D-MA), and Tom Reed (R-NY) introduced a companion bill to the House. Both proposed pieces of legislation call for "permanent authorization for NMTC, increase [d] annual credit authority [of $\$ 5$ billion] with inflation adjustments in future years, and exempts NMTC investments from the Alternative Minimum Tax" (Anderson, 2016, p. 8). While the NMTC program's future in terms of funding is unclear with the new administration, it is extremely unlikely that the NMTC will go away anytime in the near future based on the abundance of support for it from Republicans and Democrats alike. As such, it is important that financial professionals familiarize themselves with NMTCs.

\section{What are New Markets Tax Credits?}

Despite the program's widespread use and support, many of those in the field of finance-commercial banking specifically-are unclear on what the NMTC program is. In basic terms, the NMTC program is a government-sponsored program in which the government provides tax credits to big banks or other investors for financing projects in low-income communities. According to the NMTC Coalition, "there are attractive investment opportunities in low-income communities, but the cost and availability of capital in these 'New Markets' is an impediment to economic growth" (Anderson, 2016, p. 5). Further, the NMTC Coalition states that "the capital gap deprives businesses of the investment dollars they need to set up shop and expand[;] it impedes the construction or renovation of community facilities and revitalized industrial and commercial facilities that would create jobs, economic opportunity and improve the quality of life" (p. 5). Thus, the NMTC program acts as a bridge to close this "gap." NMTC projects may be funded by debt financing, equity investment, or a combination of the two. The NMTC program is unlike other government subsidy programs in that it "is designed to deliver capital to narrowly defined geographic locations: underserved census tracts that meet mandated criteria of economic distress" (Anderson, 2016, p. 8). Typical NMTC projects involve acquiring, rehabilitating, or constructing real estate, and/or expanding businesses in low-income communities. Examples include community centers, educational facilities, cultural facilities, and health-related facilities. NMTC projects often focus on creating jobs; assisting minority-owned and low-income businesses; providing quality goods, services, housing options, and affordable food options to those in low-income communities; and increasing environmental sustainability (US Bank, 2016).

\section{Purpose/Objectives of the New Markets Tax Credit Program}

The NMTC coalition states that the program was formed with the "purpose of [stimulating] private sector investment in low-income communities and build a delivery system of private for-profit and non-profit entities that could provide technical and financial assistance to economically distressed urban and rural communities" (Walker, 2010, p. 3). A report from the Metropolitan Housing \& Communities Policy Center explains that while the NMTC program has the main objective of increasing private capital investment in low-income communities, "there are ancillary program objectives that can either be extrapolated from the core objective or that follow logically from the program's rules, operations, or basic principles" (Abravanel, 2013, p.10). The report goes on to state that one can logically assume that an "ancillary objective" of the NMTC program is to benefit the inhabitants of the communities in which the projects are implemented, either directly or indirectly. Essentially, what this means is that although the official goal of the NMTC program is to spur investment in low-income communities, it truly has an even greater goal of bettering the lives of those within those communities.

\section{Design and Implementation}

The NMTC program is governed by two authoritative bodies: The Internal Revenue Service (IRS), which oversees and monitors the application of the NMTC, and the Community Development Financial Institutions (CDFI) Fund, which awards NMTC allocation authority to Community Development Entities (CDEs) on an annual basis (Reznick, 2010). The NMTC program is designed to produce a mutually beneficial outcome for all parties involved.

A publication from Deloitte explains that "the economics behind the NMTC program are rather straightforward: investors capture their required rate of return from the tax credits generated by the transaction and the borrowing business receives capital with terms far superiorto market rates or that fill a financing gap to enhance a project's viability" (Potter, 2016).

The "superior" market rates that the borrowing business receives are usually around 50 percent below market rates, and the loans typically contain a seven-year interest only period. "[Further,] most NMTC loans are made with an expectation that a portion of the total loan amount will not be repaid or cancelled" (Potter, 2016).

The above statement is a bit alarming at first glance- "most loans are made with an expectation that a portion of the total loan amount will not be repaid or cancelled" (Potter, 2016). A report published by CliftonLarsonAllen explains that businesses awarded NMTCs get "favorable, below-market financing and a forgivable loan after seven years. That means savings on debt service payments and a significant equity benefit at the end of the seven-year compliance 
period" (Drinen, 2016). This is clearly beneficial for the borrowing business, but how do the investors and lenders benefit? And how could any lender be comfortable with a borrower not fully repaying its debt? The answer is this: the investors "receive 39 percent of the federal income tax credit based on the amount invested into the project (loans and equity combined)" - five percent of which is received "in years one to three, and 6 percent in years four to seven" (Drinen, 2016).

The process by which the NMTCs are awarded is quite strenuous. To initiate the process, the business seeking funding must complete a lengthy, thorough application, which requires a detailed plan of how it, if awarded, will use the capital obtained through NMTC funding (Reznick, 2010). Many criteria must be met in order for businesses to be eligible for NMTC financing: the businesses must be in a low-income community and meet the definition of a qualified active low-income community business. Further, investments are to be made by community development entities (CDEs) in the form of a qualified equity investment (QEI). See Appendix I for definitions of low-income community, qualified active low-income community business, qualified community development entity, and qualified equity investment.

Once granted, the awardee is required to sign an Allocation Agreement with the CDFI fund, which essentially serves as the loan contact, as it outlines the terms of the loan (Reznick, 2010). If approved,

The [tax] credit provided to the investor totals 39 percent of the investment in a CDE and is claimed over a seven-year credit allowance period. In each of the firstthree years, the investor receives a credit equal to five percent of the total amount paid for the stock or capital interest at the time of purchase. For the final four years, the value of the credit is six percent annually. Investors may not redeem their investments in CDEs prior to the conclusion of the seven-year period. (Hardin, 2011, p. 27)

The Community Development Financial Institutions Fund (CDFI Fund), a branch of the Department of the Treasury, uses the guidelines outlined in section 45D of the Internal Revenue Code (IRC) to administer NMTCs.

\section{Arguments For}

In June 2016, the NMTC Coalition released The New Markets Tax Credit Progress Report 2016. Within the report, the NMTC Coalition included results from a survey titled "Community Development Entity (CDE) Survey of 2015 NMTC Activity: By the Numbers." The survey, which received 65 responses from CDEs, represents $\$ 19.1$ billion in total allocations from projects completed between 2003 and 2015. The results of the survey were striking. It reported \$1.6 billion in Qualified Equity Investments, \$1.8 billion in Qualified Low-Income Investments, and \$3.6 billion in total project financing. Further, the survey revealed that 194 businesses and projects received NMTC financing; 625 affordable housing units were created; $81.3 \%$ of NMTC investments were made in severely distressed communities; 11.5 million square feet of commercial, industrial, or community facility space constructed or renovated; and 44,992 total jobs were created or retained by projects closing in 2015 , at a cost per job of $\$ 8,667$. Of the roughly 45,000 jobs, 22,288 were full time jobs and 18,704 were construction jobs (Anderson, 2016).

As a result of the findings described above, the NMTC Coalition concludes that "the NMTC continues to serve as an effective tool for driving capital to areas of economic distress and creating jobs, revitalizing both urban and rural communities where the credits are employed" (Anderson, 2016, p. 11). Another important statistic to look at in regard to the NMTC program is how the projects are structured. As will be discussed later in the "arguments against" section of this report, some criticize the complexity of the NMTC program. More specifically, there are claims that projects can be structured in extremely complex ways, enabling participants to receive more than their fair share of benefits. The NMTC Coalition, however, found that in 2015 , a substantial " 98.6 percent of qualified equity investments reported by survey respondents utilized the leverage structure" (p. 11). In other words, nearly all NMTC Projects consist of both debt and equity financing. This concept may sound complex at first glance, but the NMTC Coalition's report shows otherwise.

The NMTC Coalition further argues that the NMTC program is "providing lower returns and more benefit to low income community businesses" (Anderson, 2016, p. 17). In fact, looking at pricing data from 2005 to 2015, prices have increased from a range of \$0.60-\$0.70 in 2005 to a range of $\$ 0.80-\$ 0.85$ in 2015. This means that NMTC investors in 2015 paid an average of $\$ 0.80-\$ 0.85$ cents on the U.S. dollar for tax credits. For example, a NMTC investor paying $\$ 0.85$ per $\$ 1.00$ of tax benefit results in $\$ 0.33(\$ 0.85 \times 39 \%)$ of NMTC equity. Thus, on a $\$ 5$ million transaction priced at $\$ 0.85$, the investor would receive approximately $\$ 1,657,500(0.3315 \times \$ 5,000,000)$ in tax credits over a seven-year period.

Pricing is particularly important because, as the report explains, "when NMTC investors pay a higher price in exchange for the credit, more benefit flows to the low-income community business" (Anderson, 2016, p. 17). While the NMTC Coalition 
is clearly in favor of the NMTC program, it does acknowledge that the program fell short in previous years. For example, as

"rural economies present unique obstacles to revitalization ... between 2003 and 2007, only 16.9 percent of NMTC investments went to rural areas" (p. 19). This number is important to consider, as "20 percent of the population resides in [rural] economies" (p. 19). Most recently, however, "nearly 25 percent of NMTC projects were located in rural communities" (p. 19).

While the NMTC program clearly dedicates a substantial amount of resources to rural economies, its overarching goal is to reach communities, whether rural or urban, in severe economic distress. The NMTC Coalition states, "As the program matured and competition for credits and allocation increased, CDEs increasingly invested in communities with higher levels of distress where conventional financing is harder to secure." For example, "According to data from the CDFI Fund between 2003 and 2007, 69.9 percent of NMTC projects were in severely distressed communities" (Anderson, 2016, p. 19). In order for a community to be considered "severely distressed," it must meet certain criteria: "unemployment rates more than 1.5 times the national average, poverty rates 30 percent or higher, or median income at or below 60 percent of the area median" (p. 19). The results of the 2003 to 2007 survey are impressive; however, those statistics further improved throughout the years. Most recently, the NMTC Coalitions survey revealed "81.3 percent of projects were located in severely distressed census tracts" (p. 19).

The NMTC Coalition is not the only entity to show support for the NMTC program. According to a 2016 report by Deloitte, titled “Credits \& Incentive Talk with Deloitte," there are many examples of the NMTC program contributing to "meaningful and transformative impacts on qualifying, low-income community businesses and the communities in which they operate." In fact,

The program has been named multiple times as one of the top contenders for the prestigious Innovations in American Government Award. In the program's first ten years, NMTC investments generated nearly $\$ 118$ billion in economic activity and created 744,267 jobs in low-income rural and urban communities ... [In addition,] NMTCs played a critical role in financing the construction of a revitalized St. Bernard Parish Hospital in Chalmette, Louisiana, devastated by Hurricane Katrina; the development of a cleantech innovation campus in Los Angeles to build a green economy and create a potential 600 new jobs; and the expansion of the San Antonio Food Bank, doubling its capacity to meet an increasing demand for healthy food distribution. (Potter, 2016)

\section{Arguments Against}

In 2014, the Government Accountability Office conducted a study of the financial structure of NMTCs. The GAO (2014) published the results of its research in a report titled New Markets Tax Credit: Better Controls and Data are Needed to Ensure Effectiveness. The GAO's purpose in conducting its research was to first assess the complexity and transparency of NMTC financial structures and controls over the size of the federal subsidies, and second, uncover information regarding the types and amounts of fees and other expenses related to the NMTC financial structure. To complete its research, the GAO reviewed data produced by the NMTC Treasury and surveyed CDEs that allocated credits over 305 projects between 2010 and 2012.

As a result of its studies, the GAO first concluded that the NMTC financial structure has "become more complex and less transparent over time" (White, 2014, p. 10). It attributes this increased complexity "in part, to combining the NMTC with other federal, state, and local government funds" (White, 2014). The GAO's report concludes that NMTC investors have, over time, developed strategies which enable the use of increased funding from both private and public sources-a process the GAO simply calls, "increasing the leverage on the investment" (p.5). The report argues that NMTC transactions are being structured in ways that increase the amount of federal subsidies available to certain projects, which the GAO believes, may lead to "projects being undertaken that would not otherwise have been started for lack of sufficient funding." Further, the GAO states that "[these strategies] also increase the complexity of the financial structures by adding more parties and more transactions, which in turn reduces transparency and may increase the cost in terms of fees and other transaction costs" (p. 5).

FIGURE 


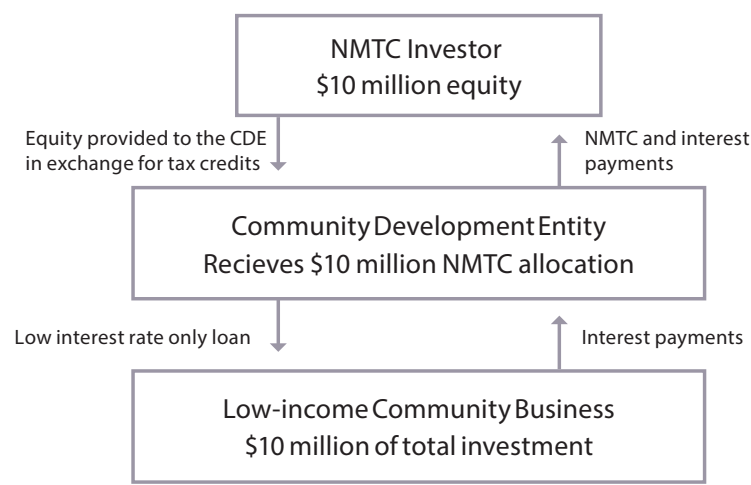

Figure 1: Simplified Example of New Markets Tax Credit (NMTC)

Basic Model

Journal of Undergraduate Research and Creativity U. S. Government Accountability Office. "New Markets Tax Credit: Better Controls and Data are Needed to Ensure Effectiveness." 2014.

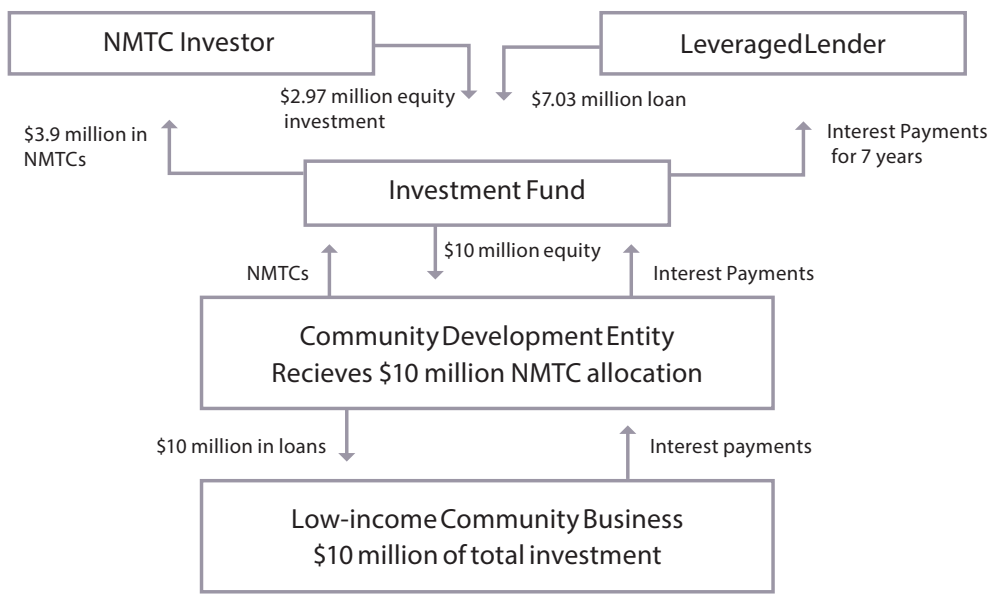

Figure 2: Simplified Example of New Markets Tax Credit (NMTC) Investment Leveraged with Private Funds

Journal of Undergraduate Research and Creativity U. S. Government Accountability Office. "New Markets Tax Credit: Better Controls and Data are Needed to Ensure Effectiveness." 2014. 


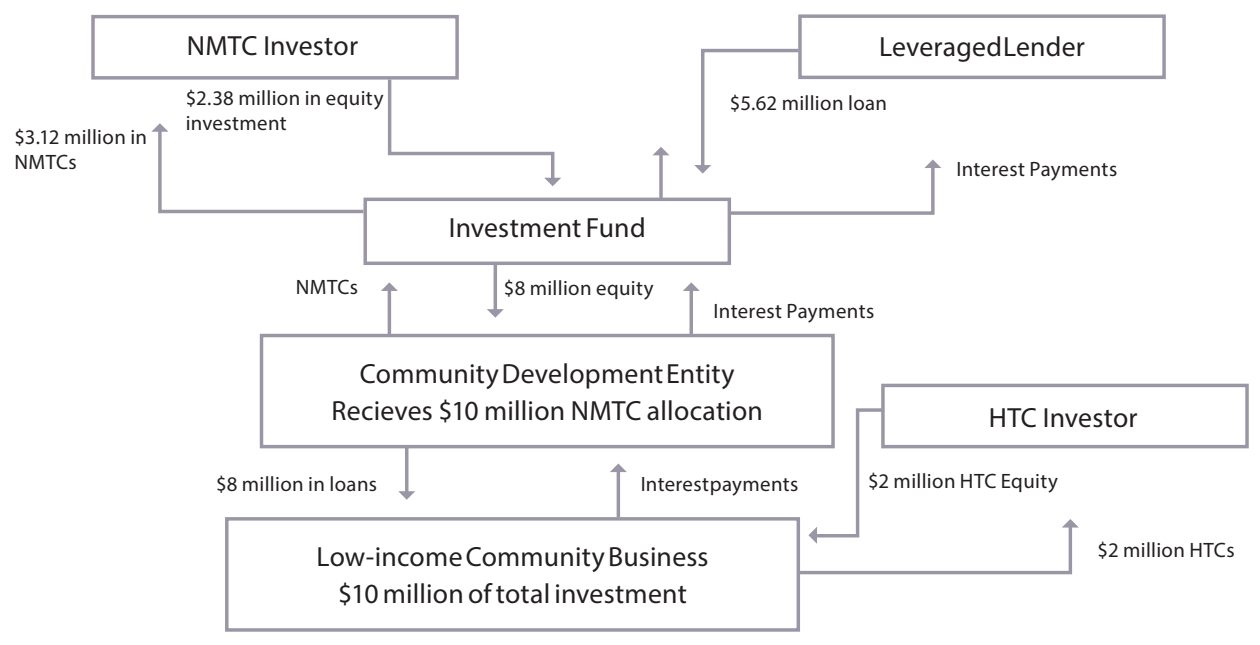

Figure 3: Simplified Example of New Markets Tax Credit (NMTC) Investment Combined (but Not Leveraged by) Other Public Funds Journal of Undergraduate Research and Creativity U. S. Government Accountability Office. "New Markets Tax Credit: Better Controls and Data are Needed to Ensure Effectiveness." 2014.

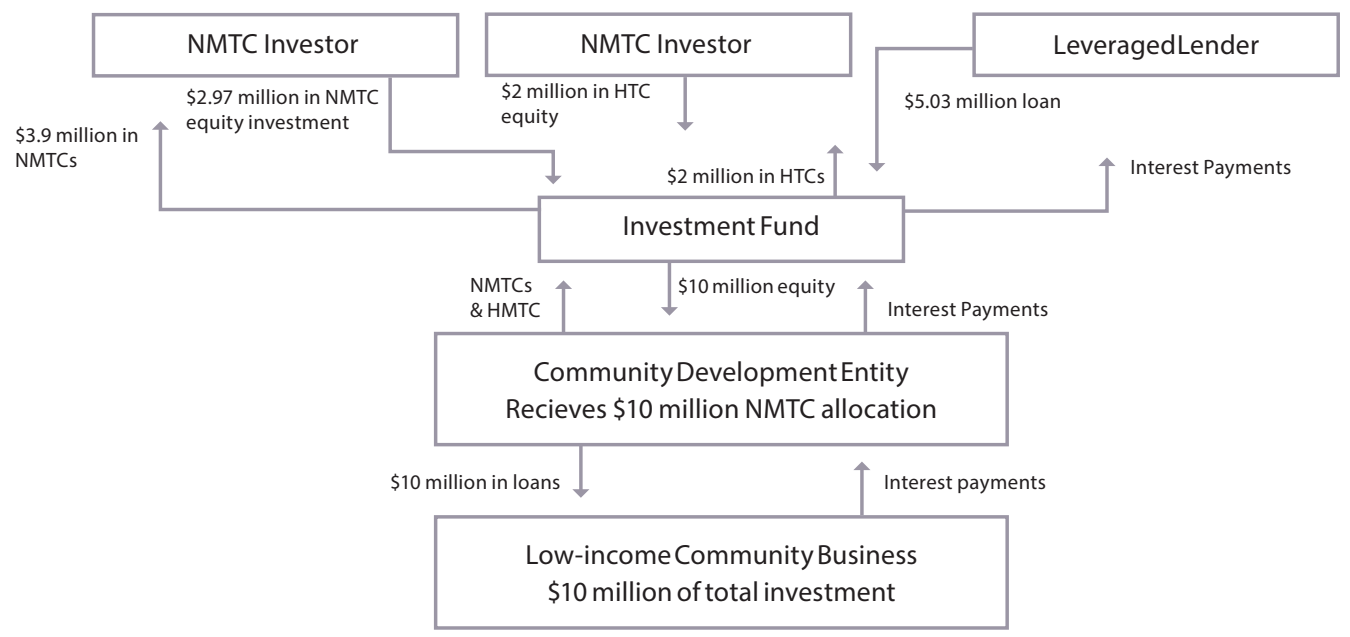

Figure 4: Simplified Example of New Markets Tax Credit (NMTC) Investment Leveraged with Both Private and Public Funds

Journal of Undergraduate Research and Creativity U. S. Government Accountability Office. "New Markets Tax Credit: Better Controls and Data are Needed to Ensure Effectiveness." 2014. 
In support of the GAO's conclusion that NMTC investments have become increasingly complex since the program's launch, it provides evidence that many NMTC projects are, in fact, more complex than what is reflected in the above examples. According to the GAO's report, despite already seeming quiet complex, the above examples fail to recognize "some of the complexities that are required for the purpose of acquiring the tax benefit" (White, 2014, p. 10). To show this complexity, the report refers to Figure 4 (shown above), in which "a pass-through entity that is disregarded for tax purposes is established to route the flow of funds back from the low-income community business to the investment fund to claim the NMTC" (p. 10). The GAO reports that this complexity in structures reduces transparency of the NMTC program "by making it more difficult to trace the flow of private and public funds and the benefits from the tax subsidies" (p. 11).

The CDFI Fund data (2014) revealed that "21 percent of projects originating in 2010 through 2012 had financial structures involving more than one CDE," and another " 21 percent of projects had four or more transactions involving financial flows (such as loans from the CDEs to the LIC business)." The GAO further estimates that "41 percent of NMTC investments weremade using one of the leveraged models in 2006, while more recent industry estimates state that more than 90 percent used such leverage in 2013" (White, 2014, p. 10).

In regard to the GAO's survey of Community Development Entities with projects originating in 2010-2012, the GAO concluded that, "[62] percent of all NMTC projects received other public funding-funds from federal, state or local public sources," with 33 percent specifically receiving other federal funding. Further, "[21] percent of all NMTC projects received funding from multiple other government programs" (White, 2014, p. 11).

The use of multiple government programs in NMTC programs reflected in the GAO's survey data, according to the GAO, "raises questions about unnecessary duplication" (White, 2014, p. 12). Currently, the CDFI Fund collects data regarding "whether other public funds are used to finance projects, but does not ask for any details such as the information on specific programs providing those funds." As such, the GAO concluded that, because of the lack of data at the time of its study, it was not possible to "determine whether unnecessary duplication is occurring" (p. 12).

Not only does the GAO discuss the possibility of redundant duplication of benefits under the NMTC program, but it also brings into question the legitimacy of market rates of return that investors receive. While some NMTC industry representatives argue that "competition for credits by potential investors and competition between CDEs for credit allocations works to ensure returns on NMTC investments are kept at market rates commensurate with NMTC investor's risk," other evidence suggests that "some investors may receive returns that are above-market and therefore more than the necessary subsidy required to attract the funds" (White, 2014, p. 13). The GAO cites research from a case study reported by the Urban Institute, in which "an investor appeared to put in about $\$ 500,000$ of NMTC equity to claim $\$ 1.2$ million of NMTCs representing a return of about 24 percent compounded annually" (p. 13).

In regards to controls over the size of federal subsidies, the GAO's 2014 report concludes, in summary, that the NMTC program is lacking in terms of controls to prevent above-market rates of return and/or unnecessary duplication and costs. The GAO recognizes that "one NMTC control has been Treasury and IRS guidance on the allowable financial structures"-more specifically, "the Secretary of the Treasury has the authority to limit how other federal tax benefits are used with the NMTC" (White, 2014, p. 14). However, the issue remains that "controls do not exist to monitor and prevent unnecessary use of other public funds to supplement the NMTC," (p. 14) which the GAO says is for multiple reasons. First, the "Treasury, through the CDFI Fund, does not collect information about the specifics of other public funding." Second, "for the CDFI Fund, Treasury does not have controls to limit the risk of cases like the exampl from the Urban Institute study where other public funds were used to expand the NMTC base and apparently generate a 24 percent rate of return for the NMTC investor" (p. 14). The GAO warns that this lack of guidance and controls may result in diluted benefits for the low-income communities partaking in the NMTC program.

In summary, the GAO's 2014 report aims to show that the NMTC program is flawed. In order to improve the program, the GAO suggests implementing controls that require CDEs to report the NMTC investor's overall rate of return on NMTC projects, which would "provide greater clarity about tax subsidies," by "allow[ing] an assessment of whether the NMTC investor is earning a market return commensurate with the risk on its own investment" (White, 2014, p.14). Further, the GAO recommends another control that requires CDEs to "justify rates of return above a certain threshold." Additionally, the GAO also suggests "caps on rate of returns and mechanisms to ensure competition among NMTC investors sufficient [enough] to prevent above-market rates of return" (p. 14).

Shortly after the GAO's release of its 2014 study, Senator Tom Coburn released a supplementary report titled "Banking on the Poor: How Corporate America Exploits Struggling Communities to Collect New Markets Tax Credits." 
Using evidence from the previously discussed report published by the GAO, Coburn develops a firm stance opposing the NMTC program. While his report is "not intended to demonize the entities receiving the funds or the projects they are supporting," his goal is to "provide some transparency for taxpayers" (Coburn, 2014, p. ii). Within the report, he claims that although "this tax credit [is] intended to benefit the poor, [it] is instead lining the pockets of the well-off, such as big banks and other private investors ... [including] JP Morgan Chase, Bank of America, and Wells Fargo" (p. ii). Coburn even goes as far as to call the NMTC a "reverse Robin Hood scheme" (p. ii). Coburn sets the tone of his article with somewhat of a humorous introduction:

Dear Taxpayer,

A billionaire's fantasy island, Emmy award winning producers, Goldman Sachs, Broadway music from Hollywood, Starbucks, and even dolphins benefited from a tax credit intended to help struggling communities and lower-income Americans seeking new opportunities.

Big banks collect millions of dollars in tax credits to help finance economic development projects, which have included doggie day cares, a sculpture in the desert, drive-in movie theaters, luxury hotels and fast food enterprises. While some of the projects are well intended, like health clinics, it is still difficult to measure if these tax expenditures are truly helping those seeking a hand up or simply subsidizing banks, corporations, and others who are already succeeding.

The federal New Markets Tax Credit program was created to steer taxpayers dollars into banks that would in turn funnel financial assistance to businesses and developers in low-income communities to help create jobs. Yet, virtually every neighborhood, from Beverly Hills to the Hamptons, could qualify for the program. . . (Coburn, 2014, p. i)

The letter goes on; however, the above excerpt paints a clear picture of the point that Senator Coburn is trying to make, which is that the NMTC program is broken. According to Coburn,

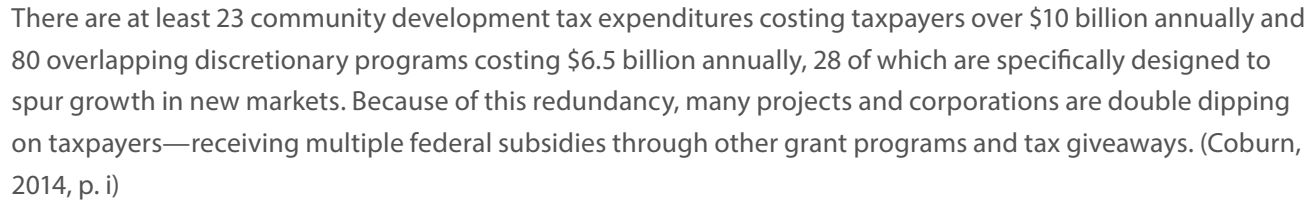

Senator Coburn (2014) further claims that the loose definition of "qualified low-income communities" allows "virtually all of the country's census tracts [to be] potentially eligible for the NMTC" (p. 1).

In addition, Coburn (2014) states: "[As] Congress continues to reauthorize the program, the effort intended to enhance private sector business activity in struggling communities [is] largely [becoming] a cash cow for big banks and others in the financial industry, while the true economic value generated by the NMTC program remains in question" (p. 3). In summary, he believes the NMTC "is just one among hundreds of handouts, credits, and deductions tucked into the code giving an unfair advantage to the well-connected and special interest groups" (p. ii).

\section{DISCUSSION}

As reflected in this report, strong arguments exist both for and against the NMTC program. Referring back to the main goal of this dissertation, which is to determine who the real winner is in regard to the NMTC program-big banks or low-income communities - this section serves to essentially analyze and rebut, if applicable, each of the arguments and criticisms against the NMTC program.

In response to the previous articles in opposition of the NMTC program, the NMTC Coalition itself released a report in an attempt to rebut the damaging claims brought forth by both the GAO and Tom Coburn. The NMTC's report (2014), titled, "New Markets Tax Credit Reports Ignore Success," states that the reports reflect a "limited understanding of the obstacles and challenges to investing in economically distressed communities." It further argues that 
although some of the GAO's recommendations are "not objectionable, the [GAO's] report itself provides little new or accurate information on the NMTC and the positive impacts NMTC investments have had in communities across the country" (NMTC Coalition, 2014). In fact, the NMTC Coalition believes that the Treasury is already implementing a number of the GAO's recommendations.

Of course, the NMTC Coalition is in place for the sole purpose of advocating for the NMTC program. As such, one must look to additional sources of information when taking a position on the effectiveness and successfulness of the NMTC program. Therefore, the remainder of this section will use further information, in addition to the support from the NMTC Coalition and what is included in the "arguments for" section, to rebut the GAO's and Tom Coburn's stances on the NMTC program.

\section{Complexity}

The GAO's report claims that a significant number of projects are structured to use funds from more than one CDE, making the transactions too complex, less transparent, and difficult to trace. The GAO is correct in the sense that, yes, many projects do involve more than one CDE. Because the transaction involves more parties, it does become slightly more complex; however, that does not necessarily mean that the transaction is less transparent or difficult to trace. As discussed earlier, the NMTC program is highly regulated and highly competitive. Participants must pass through an extensive application and selection process to even be considered for the program. Further, because the NMTC program is a governmentally sponsored program, there are federal records of every NMTC project and all participants. While this information is not readily available to the general public, it does exist for those who have authority over and provide oversight for the program.

\section{Redundant Duplication}

The GAO and Tom Coburn also discuss the possibility of unnecessary duplication. While the GAO admits it did not obtain sufficient evidence to substantiate the claim due to its collected data lacking detail on specific programs providing addition funding to NMTC recipients, Tom Coburn stands behind his argument. Interestingly enough, Tom Coburn uses the GAO's data to substantiate the majority of his claims in his article, "Banking on the Poor;" however, he does not acknowledge the GAO's determination that it could not take a firm stance on whether unnecessary duplication is occurring.

In response to Coburn's claim that there are numerous federal incentive programs that benefit big banks, which seemingly overlap, the NMTC Coalition (2014) insists that the NMTC program is the "only federal incentive that is primarily intended to drive capital to credit-starved businesses in economically distressed urban and rural communities." The NMTC Coalition goes as far as to call the role of the NMTC "the federal government's single largest and most effective tool for community revitalization" (NMTC Coalition, 2014).

There were, in fact, two pieces of legislation that served a similar purpose: The Recovery Zone Bonds and Tribal Economic Development Bonds; however, both incentive plans expired at the end of 2010. Another noteworthy incentive is the Section 179 deduction, which allows businesses within Empowerment Zones in one of less than 100 low-income communities to claim deductions for certain assets. However, it is not similar to NMTC in that it "does not directly incentivize outside financing" (NMTC Coalition, 2014).

\section{Excessive Returns}

Another argument brought against the NMTC program by both the GAO and Tom Coburn is that investors receive above-market rate returns that far exceed the minimum return that would drive investors to invest in these low-income community businesses. This argument is rather easy to disprove, as the GAO left out a significant piece of information when citing the Urban Institute's example as evidence. Recall in the "arguments against" section of this report, the Urban Institute found a case in which an investor "appeared" to invest $\$ 500,000$ of NMTC equity, gaining $\$ 1.2$ million in NMTCs in return. Further research shows that the Urban Institute itself concluded that "because of the complex financial structure, [it] could not rule out on the possibility that the investor supplied other, non-NMTC funds to the project and at a lower rate of return." (White, 2014, p. 13). In other words, the Urban Institute lacked adequate information to validate the exact amount of NMTC investment, or the amount of return the investor received in the form of tax credits.

Expecting investors to take on high risk investments—-such as those in low-income communities-only to receive little or no return, is unrealistic. Just as any investor, NMTC investors do and should gain from their investments. What is unique about the NMTC program, however, is that "regulations generally require that at least 85 percent of QEI proceeds be invested in Qualified Low-Income Community Investments (QLICIs)" (Donovan, 2016). In fact, according to the NMTC program Award Book 2015-2016, "all 120 of the 2015-2016 allocations indicated that they would invest 
at least 95 percent of QEI dollars into QLICIs. In real dollars, this means at least $\$ 889$ million above and beyond what is minimally required by the NMTC program will be invested in low-income communities" (Donovan, 2016). In other words, although only 85 percent of investor returns from NMTC projects are required to be reinvested in QLICIs, investors are going above and beyond and reinvesting approximately 95 percent of their earnings back into NMTC projects.

\section{Lenient Selection Process}

An additional argument against the NMTC program is that, in the words of Tom Coburn, "virtually every neighborhood, from Beverly Hills to the Hamptons, could qualify for the program" (Coburn, 2014, p. i). A case study by Doug Bystry (2005), President and CEO of Clearinghouse CDFI, acknowledges that the program has a reputation of being "difficult to use," noting "the laborious application, fierce competition, and expensive legal costs have scared off all but the most dedicated community development practitioners" (p. 37). However, despite the strenuous process to obtain NMTC funding, Bystry says: "But for all of its real and exaggerated challenges and obstacles, the program has enabled groups like ours, the Clearinghouse CDFI, to make community-enhancing loans in low-income areas that otherwise would not have been considered" (p. 37).

In regard to the application process, "the Clearinghouse CDFI, which is a certified CDE, has been successful in obtaining two of the first three rounds of NMTC competition for a total of $\$ 131$ million" (Bystry, 2005, p. 37). What is important to note, however, is that "of the total of824 applicants in all three rounds, only 170 (20 percent) have been successful" (p. 37). Bystry further states that "this ratio of winners to losers has fostered the impression that successful applicants have accomplished something really special" (p. 37).

The significance of this case study is that it acknowledges the difficulty in obtaining NMTC financing; however, it shows that it is, in fact, possible to do so. This case is just one example of a recipient successfully completing the application process, and the struggle in doing so. Looking deeper into the claim that NMTC Financing is easily obtainable, the Congressional Research Service commented, "As a result of the definition of low income communities, virtually all of the country's census tracts are potentially eligible for the NMTC" (Coburn, 2014, p. 1). This claim is easily disproved with the following statistic:

\footnotetext{
Of the 74,134 census tracts in America, only 30,099 qualify (41 percent). Most NMTC projects are located in the poorest of those 30,099 census tracts. 29.5 percent of census tracts are designated as 'severely distressed,' and according to the NMTC Coalition's survey of 2013 NMTC projects, 80 percent of investments went to those severely distressed census tracts. (NMTC Coalition, 2014)
}

In addition to having strict requirements and an extensive application process, the NMTC program is forced to be selective due to the fact that "allocation demand is more than six times availability," (Anderson, 2016, p. 17) according to the NMTC Coalition's 2016 Progress Report. The NMTC states, "the demand from CDEs for NMTC allocation continues to far outstrip NMTC availability" (p. 16). In fact, “CDEs requested $\$ 314.7$ billion in allocation authority between 2003 and 2015 while the CDFI fund made $\$ 50.6$ billion in allocation availability" (p.16).

The letter goes on; however, the above excerpt paints a clear picture of the point that Senator Coburn is trying to make, which is that the NMTC program is broken. According to Coburn,

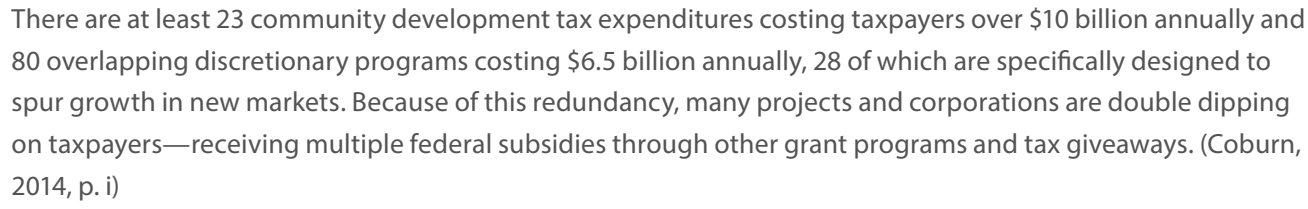

Senator Coburn (2014) further claims that the loose definition of "qualified low-income communities" allows "virtually all of the country's census tracts [to be] potentially eligible for the NMTC" (p. 1). 


\section{CONCLUSION}

After analyzing the literature both in opposition and in support of the NMTC program, I have found there is more concrete evidence that the NMTC program is, in fact, working as it was originally intended. The GAO's 2014 report made many claims against the legitimacy of theNMTC program that were based on inaccurate information and skewed data. The GAO and Tom Coburn alike claim the NMTC program has become increasingly complex throughout the years, and thus, less transparent. While it is true that individual transactions may be difficult for the average person to grasp, general information regarding NMTC project financing is readily available to the public through the United States government.

The GAO and Tom Coburn further claim that the NMTC program is duplicative of other federal programs. In fact, the GAO claims that a majority of NMTC projects combine other public funds; however, survey data published by the GAO itself showed otherwise-with federal subsidies only accounting for 17 percent of total NMTC project financing in 2011 and 2012 (NMTC Coalition, 2014). There is no evidence of any other legislation with the same design and goal as the NMTC program.

The GAO also claimed that NMTCs allow investors to claim credits based on a value much higher than the amount of money actually invested in the project but later conceded, admitting it lacked evidence to substantiate that claim. Lastly, the opposing articles claim that NMTCs are too easily obtained; however, studies show that participants must pass through an extensive application process. Even then, the demand for NMTC funding far exceeds the amount of available funding. Thus, for that reason alone, the program is forced to be highly selective.

In conclusion, the NMTC program is working as intended. Its biggest flaw, however, is its scarce availability of funding. As previously stated, allocation demand is greater than six times the availability. Thus, expanding the NMTC program and increasing funding would eliminate the need for businesses to search elsewhere (i.e., other governmental programs) to obtain necessary funds to grow their businesses. The program greatly benefits low-income businesses, and many of these communities will suffer if the legislation is not renewed. It is important to note, however, that the NMTC program does not solely benefit low-income communities-it benefits surrounding communities as well, and the United States economy as a whole.

\section{APPENDIX 1}

Low-Income Community: “The term 'low-income community' means any population census tract if- (A) the poverty rate for such tract is at least 20 percent, or (B)(i) in the case of a tract not located within a metropolitan area, the median family income for such tract does not exceed 80 percent of statewide median family income, or (ii) in the case of a tract located within a metropolitan area, the median family income for such tract does not exceed 80 percent of the greater of statewide median family income or the metropolitan area median family income" (IRC §45D).

Qualified Community Development Entity: “The term 'qualified community development entity' means any domestic corporation or partnership if- (A) the primary mission of the entity is serving, or providing investment capital for, low-income communities or low-income persons, (B) the entity maintains accountability to residents of low-income communities through their representation on any governing board of the entity or on any advisory board to the entity, and (C) the entity is certified by the Secretary for purposes of this section as being a qualified community development entity" (IRC §45D).

Qualified Equity Investment: “The term 'qualified equity investment' means any equity investment in a qualified community development entity if - (A) such investment is acquired by the taxpayer at its original issue (directly or through an underwriter) solely in exchange for cash, (B) substantially all of such cash is used by the qualified community development entity to make qualified low-income community investments, and (C) such investment is designated for purposes of this section by the qualified community development entity" (IRC §45D). 
Qualified Active Low-Income Community Businesses: "The term 'qualified active low-income community business means, with respect to any taxable year, any corporation (including a nonprofit corporation) or partnership if for such year- (i) at least 50 percent of the total gross income of such entity is derived from the active conduct of a qualified business within any low-income community, (ii) a substantial portion of the use of the tangible property of such entity (whether owned or leased) is within any low-income community, (iii) a substantial portion of the services performed for such entity by its employees are performed in any low-income community, (iv) less than 5 percent of the average of the aggregate unadjusted bases of the property of such entity is attributable to collectibles other than collectibles that are held primarily for sale to customers in the ordinary course of such business, and (v) less than 5 percent of the average of the aggregate unadjusted bases of the property of such entity is attributable to nonqualified financial property" (IRC §45D). 


\section{REFERENCES}

Abravanel, Martin D. “New Markets Tax Credit (NMTC) Program Evaluation.” Urban Institute. 2013. https://www. urban.org/research/publication/new-markets-tax-credit-nmtc-program-evaluation

Bystry, Doug. "Case Study from Application to Construction: Clearinghouse CDFI Puts New Markets Tax Credits to Work." Community Development and Investment Review. No.1 (2005): 37-42. http://EconPapers. repec.org/RePEc:fip:fedfcr:y:2005:p:37-42:n:v.1no.1

Clinton-Gore Administration. “President William J. Clinton: Eight Years of Peace, Progress, and Prosperity.” US National Archives. Archived Presidential Websites Collection. https://clintonwhitehouse5.archives.gov/ WH/Accomplishments/index.html

Coburn, Tom. Banking on the Poor: How Corporate America Exploits Struggling Communities to Collect New Markets Tax Credits. CreateSpace Publishing. 2014. Print.

Donovan, Annie. NMTC Program Award Book CY 2015-2016. US Dept. Of Treasury. 2016. https://www.cdfifund. gov/Documents/FINAL\%202015\%202016\%20NMTC\%20Award\%20Book\%20Nov2016.pdf

Drinen, Matt. “Billions in New Markets Tax Credits Available in 2016-17.” Clifton Larson Allen. August 2016. http://www.claconnect.com/resources/articles/billions-in-new-markets-tax-credits-available-in-2016

Fiore, Nicholas J. “The Community Renewal Tax Relief Act of 2000.” Journal of Accountancy. 192.2 (2001): 48. http://go.galegroup.com/ps/retrieve.do?tabID=T002\&resultListType=RESULT_LIST\&searchResult sType=SingleTab\&searchType=AdvancedSearchForm\&currentPosition=1\&docId=GALE\% 7CA77050145\&docType=Article\&sort=RELEVANCE\&contentSegment=\&prodId=GPS\&contentSet= GALE\%7CA77050145\&searchId=R1\&userGroupName=txshracd2573\&inPS=true

Hardin, Russel J. and Thomas G. Noland. "An Analysis of New Markets Tax Credits.” Real Estate Issues. 36.3 (2011): 27-36. https://www.cre.org/wp-content/uploads/2017/04/New_Markets_Tax_Credits_36_3.pdf

Mahapatra, Robin. (2012). “The New Markets Tax Credit.” Journal of Taxation \& Regulation of Financial Institutions. 25.6 (2012): 5-11.

McDonald, Steve, et. al. “The New Markets Tax Credit Progress Report 2016.” New Markets Tax Credit Coalition. http://nmtccoalition.org/wp-content/uploads/NTMC-Coalition-Progress-Report-2016.pdf

New Markets Tax Credit Coalition. "The New Markets Tax Credit 10th Anniversary Report." 2010. http://nmtccoa lition.org/wp-content/uploads/NMTCC-10th-Anniversary-Report.pd

NMTC Coalition. "New Markets Tax Credit Reports Ignore Success.” 2014. http://nmtccoalition.org/new-marketstax-credit-reports-ignore-success/

Pappas, Dimitri. "A New Approach to a Familiar Problem: The New Market Tax Credit." Journal of Affordable Housing \& Community Development Law. 10.4 (2001): 323-52. http://www.jstor.org/stable/25782506.

Potter, Kevin \& Jarick Poulson. “Navigating a Rewarding Financial Tool: New Markets Tax Credit.” Journal of Multistate Taxation and Incentives. 26.6 (2016): n.p.https://www2.deloitte.com/us/en/pages/tax/ articles/navigating-a-rewarding-financing-tool-new-markets-tax-credit.html

Perlow, Gary. "Investing in Distressed Communities: The New Marikets Tax Credit Program." Mondaq. 2010. http://www.mondaq.com/unitedstates/x/104426/tax+authorities/Investing+in+Distressed+Communi 
ties+The+New+Markets+Tax+Credit+Program

“Presidential Approval Ratings-Bill Clinton.” Gallup News. 2013.http://www.gallup.com/poll/116584/presiden tial-approval-ratings-bill-clinton.aspx

Rapoza Associates, \& Novogradac \& Company LLP. "NMTC Economic Impact Report: The New Markets Tax Credit." 2012. http://nmtccoalition.org/wp-content/uploads/NMTC-Economic-Impact-Report.pdf

US Bank. “The Basics: New Market Tax Credits.” https://www.usbank.com/commercial-business/tax-credit-fi nancing/new-markets-tax-credits-basics.html 